\title{
On the Electrogenic Nature of Active Sodium Transport across the Isolated Frog Skin *
}

\author{
Saulo Klahr and Neal S. Bricker $\dagger$ \\ (From the Renal Division, Department of Internal Medicine, Washington University School \\ of Medicine, St. Louis, Mo.)
}

For many cell types, including the frog skin epithelia, it has been assumed that active transport of sodium across plasma membranes occurs as a nonelectrogenic process in which sodium and potassium movements are coupled in a $1: 1$ ratio (1). The usual schema depicts a carrier crossing the plasma membrane in one direction with a sodium ion and returning with a potassium ion. For every cation actively transferred out of the cell via such a mechanism, one cation would be pumped back in, and there would be no net transfer of electric charge. According to the hypothesis of Koefoed-Johnsen and Ussing (1), the nonelectrogenic sodium pump is located at the internal border of the frog skin epithelial cells, and the short-circuit current (which is a measure of the transcellular movement of electric charge) is attributable to the diffusion of sodium ions into the cell across the external plasma membrane and the diffusion of an equal number of potassium ions out of the cell across the internal plasma membrane. Thus the current would depend upon the passive diffusion of $\mathrm{K}^{+}$out of the cell. Under steady-state conditions, however, the number of sodium ions extruded via a linked pump and the number of potassium ions diffusing out of the cell passively would be equal; hence, there would be an equality between the short-circuit current and active sodium transport despite the nonelectrogenicity of the pump.

* Submitted for publication October 21, 1963 ; accepted January 6, 1964.

Supported by the National Institutes of Health (grant A-2667); the Department of the Army, Research and Development Branch (contract no. DA-49-007-MD-772) ; and a grant-in-aid from the American Heart Association.

A preliminary report of these data was presented at the 55th Annual Meeting of the American Society for Clinical Investigation, and an abstract has been published (J. clin. Invest. 1963, 42, 920).

$\dagger$ Performed during the tenure of an established investigatorship of the American Heart Association.
To date, the evidence for nonelectrogenic sodium transport in the frog skin, as well as other polar epithelial cell systems, is largely circumstantial. Moreover, recent studies (2) suggested that active sodium transport across the isolated frog skin might account for net transfer of electric charge. In the latter experiments, the internal surface of the frog skin was exposed to potassium concentrations equal to or greater than estimated intracellular potassium values, and the skins were maintained under conditions of complete short-circuiting. These events were designed to eliminate both the electrical and the chemical gradients favoring net passive potassium movement from cell water to internal medium and thereby to diminish or abolish any contribution of potassium diffusion to the observed shortcircuit current and spontaneous transcellular potential difference. Positive charge could enter the cell water from the external solution across the external border of the epithelia, via sodium diffusion, but positive charge should not leave the cells across the internal border via potassium diffusion. Were the sodium pump nonelectrogenic, there would then be no net movement of positive electric charge attributable to either sodium or potassium ions across the internal border of the epithelia. However, an appreciable short-circuit current persisted, thus indicating that electric charge crossed both borders of the cells. These electrical measurements, supported by sodium flux studies, suggested that the charge transfer across the internal border was a function of active electrogenic sodium transport. On the other hand, chloride was the predominant anion in the Ringer's solutions in which the frog skins were suspended, and a significant chloride current could not be excluded definitively.

The present studies were performed using chloride-free bathing media. The Ringer's solutions in contact with the internal surface of the isolated 
TABLE I

Composition of Ringer's solutions

\begin{tabular}{|c|c|c|c|c|c|c|c|}
\hline & $\mathrm{Na}^{+}$ & $\mathbf{K}^{+}$ & $\mathrm{Ca}^{++}$ & $\mathrm{Cl}^{-}$ & $\mathrm{HCO}_{3}^{-}$ & SO:- & $\mathrm{PO}_{4}^{-}$ \\
\hline Frog Na Ringer's & $\begin{array}{l}\text { mmoles } / L \\
115\end{array}$ & $\begin{array}{c}\text { mmoles } / L \\
2.4\end{array}$ & $\begin{array}{c}\text { mmoles } / L \\
1.2\end{array}$ & $\begin{array}{c}\text { mmoles } / L \\
117.4\end{array}$ & $\begin{array}{c}\text { mmoles } / L \\
2.4\end{array}$ & $\begin{array}{l}\text { mmoles } / L \\
0\end{array}$ & $\begin{array}{l}\text { mmoles } / I . \\
0\end{array}$ \\
\hline \multicolumn{8}{|l|}{ Sulfate Ringer's I } \\
\hline $\begin{array}{l}\mathrm{Na}_{2} \mathrm{SO}_{4} \\
\mathrm{~K}_{2} \mathrm{SO}_{4}\end{array}$ & $\begin{array}{c}120 \pm 3 \\
0-6\end{array}$ & $\begin{array}{c}0-6 \\
120 \pm 3\end{array}$ & $\begin{array}{l}1.3 \\
1.3\end{array}$ & $\begin{array}{l}\mathbf{0} \\
\mathbf{0}\end{array}$ & $\begin{array}{l}\mathbf{0} \\
\mathbf{0}\end{array}$ & $\begin{array}{l}57.6 \pm 1 \\
57.6 \pm 1\end{array}$ & $\begin{array}{l}2.0 \\
20\end{array}$ \\
\hline \multicolumn{8}{|l|}{ Sulfate Ringer's II } \\
\hline $\begin{array}{l}\mathrm{Na}_{2} \mathrm{SO}_{4} \\
\mathrm{~K}_{2} \mathrm{SO}_{4}\end{array}$ & $\underset{0-6}{165} \pm 5$ & $\begin{array}{c}0-6 \\
165 \pm 5\end{array}$ & $\begin{array}{l}1.3 \\
1.3\end{array}$ & $\begin{array}{l}\mathbf{0} \\
\mathbf{0}\end{array}$ & $\begin{array}{l}\mathbf{0} \\
\mathbf{0}\end{array}$ & $\begin{array}{l}84 \pm 1 \\
84 \pm 1\end{array}$ & $\begin{array}{l}2.0 \\
2.0\end{array}$ \\
\hline
\end{tabular}

frog skin contained either $120 \pm 3$ or $165 \pm 5$ $\mathrm{mEq}$ per $\mathrm{L}$ of potassium, and the external bathing media contained equimolar concentrations of sodium. The principal anion was sulfate, and the only other anion in the bathing media was phosphate, which was present in a concentration of 2 mmoles per L. By employing potassium concentrations in excess of estimated intracellular values in contact with the internal surface of the skin and relatively impermeable anions in contact with both surfaces of the skin, not only potassium but anionic diffusion currents could be excluded as important events in maintaining a short-circuit current. The data are consistent with the view that sodium transport occurs as an electrogenic process.

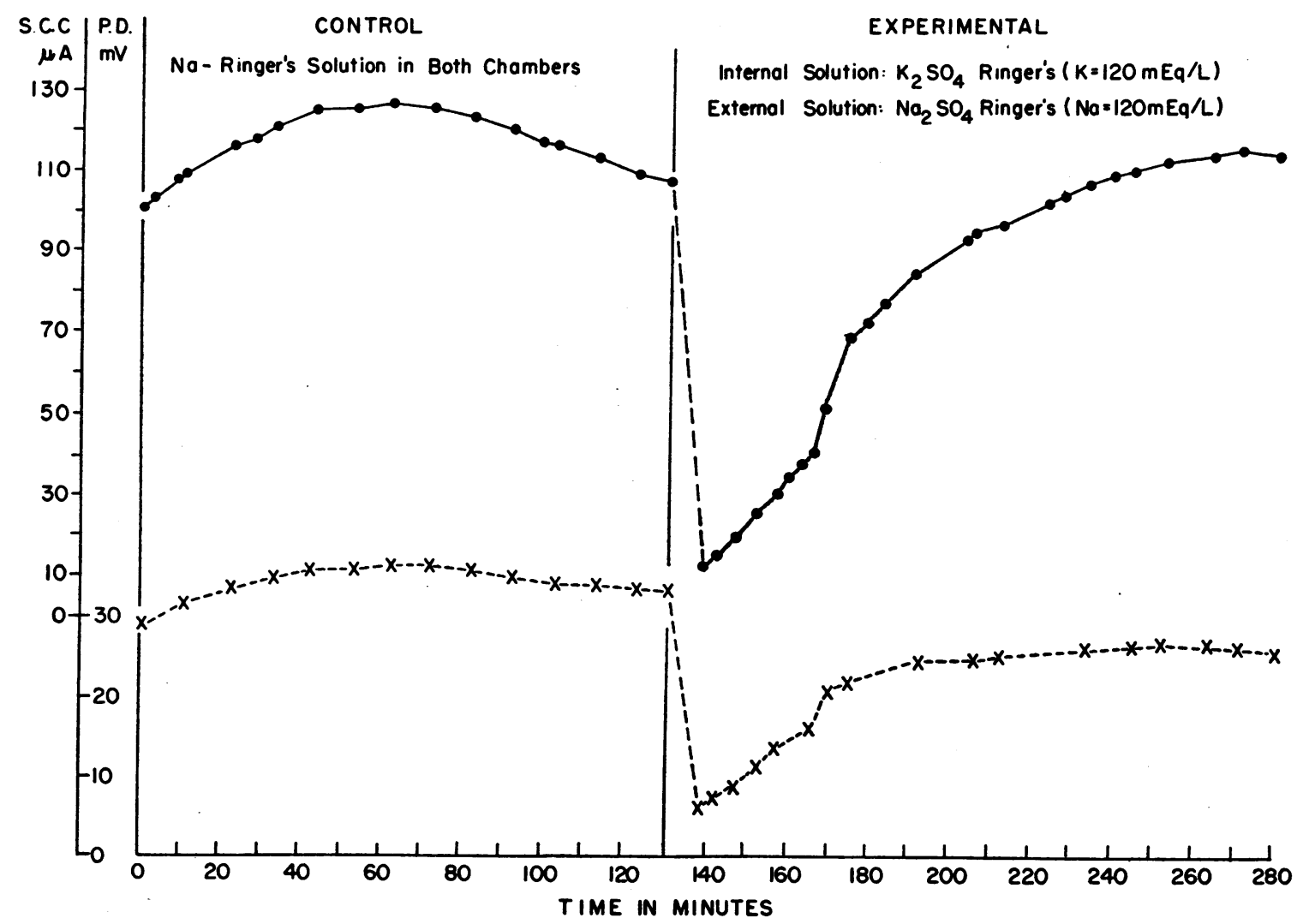

Fig. 1. VAlues for Short-Circuit current ( $\mathrm{SCC}, 0$ ) AND transbladder potential difference $(\mathrm{PD}, \times)$ in A REPRESENTATIVE EXPERIMENT. SCC in $\mu$ a per $7 \mathrm{~cm}^{2}$ of bladder; PD in $\mathrm{mv}$. 


\section{Methods}

Isolated frog skins from Rana pipiens were suspended as diaphragms between two symmetrical lucite hemichambers. Twenty to $25 \mathrm{ml}$ of appropriate Ringer's solution was added to each hemichamber; constant mixing and oxygenation were obtained by bubbling room air or $100 \%$ oxygen through the respective solutions. The short-circuit current and potential difference across the skins were measured by standard techniques (3). The skins were maintained under conditions of complete short-circuiting except for the brief intervals required to measure the potential difference approximately every 10 minutes. In the majority of experiments, preliminary measurements were obtained with conventional frog sodium Ringer's solutions in both hemichambers. Steadystate conditions generally were achieved within 30 to 60 minutes, after which three control periods, each of approximately 30 minutes duration, were obtained. The frog Ringer's solutions then were removed, and potassium sulfate Ringer's solution was added to the internal chamber and sodium sulfate Ringer's to the external chamber. These solutions were changed one or more times during the ensuing 15 to 30 minutes. After new steady-state conditions had been achieved, three 30-min- ute periods were obtained. In a number of experiments, strophanthin then was added to the internal solution in a $1.4 \times 10^{-5} \mathrm{M}$ final concentration, and additional measurements were made.

The agar bridges in contact with the Ringer's solutions had the same ionic composition as the bathing media; the composition of the various solutions is shown in Table I. Two types of sulfate Ringer's solutions were employed. In those designated as $\mathrm{I}$, the potassium concentration of the $\mathrm{K}_{2} \mathrm{SO}_{4}$ Ringer's and the sodium concentration of the $\mathrm{Na}_{2} \mathrm{SO}_{4}$ Ringer's were $120 \pm 3 \mathrm{mEq}$ per $\mathrm{L}$. In the solutions designated as II, the $\mathrm{Na}^{+}$and $\mathrm{K}^{+}$concentrations were $165 \pm 5 \mathrm{mEq}$ per $\mathrm{L}$, respectively. All solutions were buffered with potassium or sodium phosphate, and the majority of observations was made at a $\mathrm{pH}$ of 7.4, although experiments also were performed at $\mathrm{pH}$ levels of 7.0 and 8.4. In all experiments, the $\mathrm{pH}$ and osmolality of the solutions bathing the opposite surfaces of the skin were equal.

Isotopic fluxes were measured with $\mathrm{Na}^{22}, \mathrm{Na}^{24}, \mathrm{~S}^{35}$, and $\mathrm{P}^{32}$. The isotopes were added 20 to 30 minutes before measurements were initiated, and when the frog Ringer's solutions were removed and replaced with sulfate Ringer's solutions, new isotopes were added, and another period of equilibration was allowed.

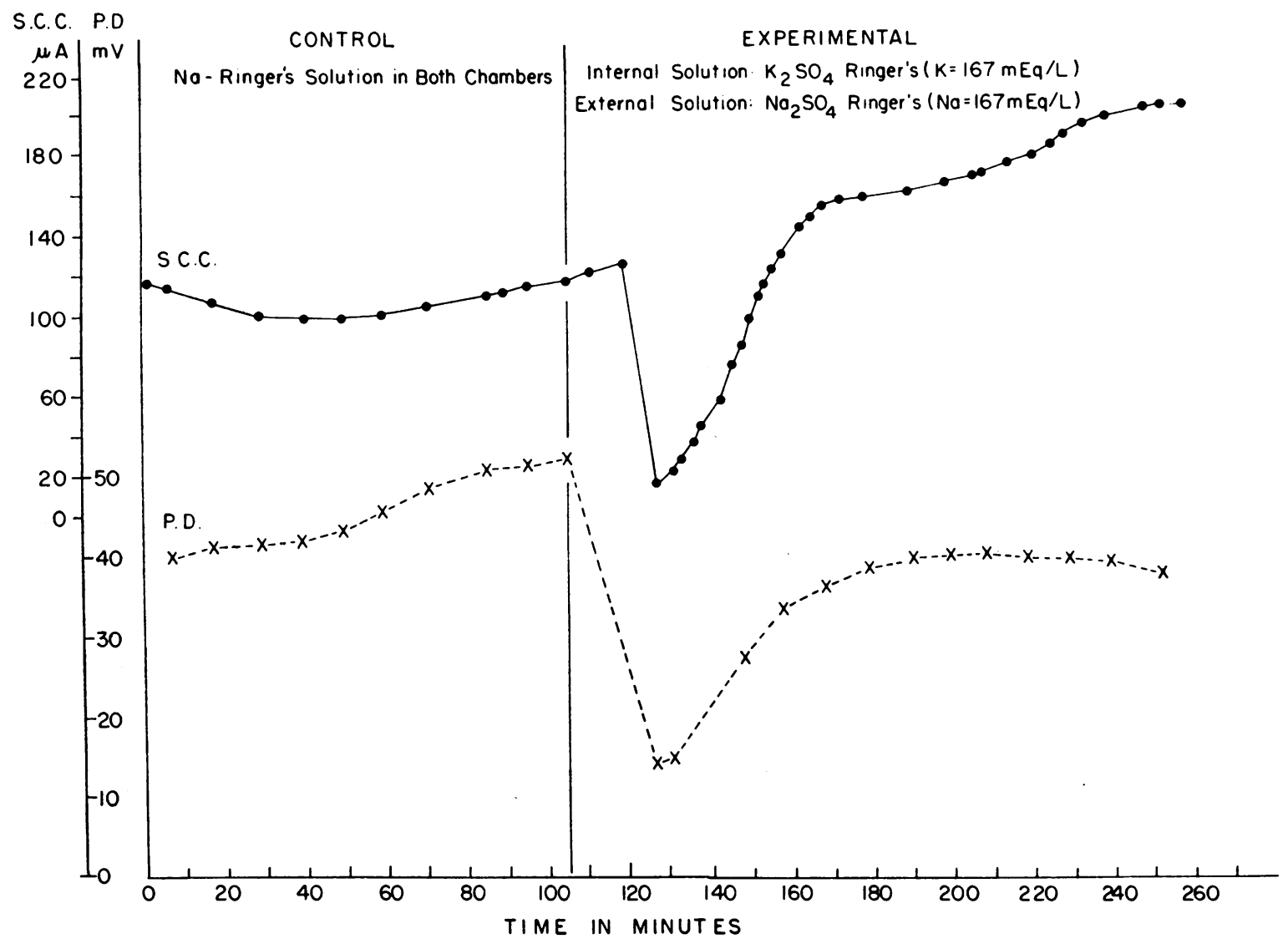

Fig. 2. VAlues for SCC ANd PD in a RePresentative experiment. For abbreviations, see Figure 1. 
TABLE II

Relationship of Na influx to short-circuit current (SCC)

\begin{tabular}{lcccc}
\hline \multicolumn{1}{c}{ Conditions } & $\begin{array}{c}\text { No. of } \\
\text { experiments }\end{array}$ & SCC & Na influx & Na influx \\
SCC
\end{tabular}

* Figures in parentheses are standard deviations.

† Mean calculated from the mean value of each individual experiment.

$\ddagger$ Both values differ significantly from $100 \%$ ( $p<0.01$ ).

Unidirectional sodium flux measurements were performed with tracer quantities of $\mathrm{Na}^{22}$. Bidirectional sodium flux studies were performed with $\mathrm{Na}^{23}$ in the external chamber for measurement of influx, and $\mathrm{Na}^{24}$ in the internal chamber for measurement of efflux. The two sodium isotopes were counted with an auto gamma spectrometer (Packard model 410A) before and after decay of the $\mathrm{Na}^{24}$. Influx and efflux rates of sulfate were measured isotopically in separate experiments. Similar measurements were made of the unidirectional flux rates of phosphate. $\mathrm{P}^{32}$ and $\mathrm{S}^{35}$ were counted in a thin endwindow gas flow counter (Tracerlab). Net potassium entry into the external solution was measured chemically with a flame photometer.

\section{Results}

The values for potential difference (PD) and short-circuit current (SCC) from a representative experiment using sulfate Ringer's solutions containing $120 \mathrm{mEq}$ per $\mathrm{L}$ of $\mathrm{Na}$ and $\mathrm{K}$ in the external and internal solutions, respectively (i.e., solutions I, Table I), are shown in Figure 1. The control observations were obtained with conventional frog Ringer's solutions bathing both surfaces of the skin. After adding the sulfate Ringer's solutions, the potential difference and short-circuit current fell precipitously. Values increased subsequently, however, and ultimately tended to reach a plateau. After steady-state conditions were achieved in experiments of this type, the values for potential difference ranged from 40 to $120 \%$ (average, $60 \%$ ) of the control values, and those for short-circuit current ranged from 50 to $150 \%$ (average, $80 \%$ ) of control values. In Figure 2, a typical experiment is shown in which the concentrations of $\mathrm{Na}$ and $\mathrm{K}$ in the sulfate Ringer's solutions were $167 \mathrm{mEq}$ per L (solutions II, Table I). The results are qualitatively the same as those depicted in Figure 1.

The relationship between $\mathrm{Na}^{22}$ influx (from external to internal solutions) and short-circuit current is shown in Table II. With frog Ringer's solutions in both hemichambers, sodium influx rates exceeded the short-circuit current by an average of $8.7 \%$. With sulfate Ringer's solutions $\mathrm{I}$, influx exceeded the current by $16.6 \%$; with

TABLE III

Relationship of Na efflux to short-circuit current

\begin{tabular}{|c|c|c|c|c|}
\hline Conditions & $\begin{array}{c}\text { No. of } \\
\text { experiments }\end{array}$ & $\mathrm{SCC}$ & $\mathrm{Na}^{22}$ efflux & $\begin{array}{l}\text { Na efflux } \\
\text { SCC }\end{array}$ \\
\hline Control (frog Ringer's) & 5 & $\begin{array}{c}\mu a / 7 \mathrm{~cm}^{2} \\
135.8 \\
( \pm 54.7)^{*}\end{array}$ & $\begin{array}{c}\mu a / 7 \mathrm{~cm}^{2} \\
22.2 \\
( \pm 7.8)\end{array}$ & $\begin{array}{c}\% \\
18.2 \dagger \\
( \pm 8.56)\end{array}$ \\
\hline $\begin{array}{l}\mathrm{K}_{2} \mathrm{SO}_{4} \mathrm{I} \text { inside, } \\
\mathrm{Na}_{2} \mathrm{SO}_{4} \text { I outside }\end{array}$ & 3 & $\begin{array}{r}93.0 \\
( \pm 35.1)\end{array}$ & $\begin{array}{l}0.50 \\
( \pm 0.14)\end{array}$ & $\begin{array}{c}0.69 \dagger \\
( \pm 0.43)\end{array}$ \\
\hline $\begin{array}{l}\mathrm{K}_{2} \mathrm{SO}_{4} \mathrm{II} \text { inside, } \\
\mathrm{Na}_{2} \mathrm{SO}_{4} \text { II outside }\end{array}$ & 3 & $\begin{array}{c}148.7 \\
( \pm 25.3)\end{array}$ & $\begin{array}{c}0.77 \\
( \pm 0.13)\end{array}$ & $\begin{array}{c}0.55 \dagger \\
( \pm 0.05)\end{array}$ \\
\hline
\end{tabular}

* Figures in parentheses are standard deviations.

$\dagger$ Mean calculated from the mean value of each individual experiment 
TABLE IV

Relationship of $\mathrm{Na}^{+}$minus $\mathrm{K}^{+}$current to short-circuit current

\begin{tabular}{|c|c|c|c|c|c|c|}
\hline Conditions & $\begin{array}{c}\begin{array}{c}\text { No. of } \\
\text { experiments }\end{array}\end{array}$ & $\mathrm{Na}^{22}$ influx & $\mathrm{K}^{+}$efflux* & $\mathrm{Na}-\mathrm{K}$ flux & SCC & $\underset{\text { SCC }}{\mathrm{Na} K \text { flux }}$ \\
\hline $\begin{array}{l}\mathrm{K}_{2} \mathrm{SO}_{4} \mathrm{I} \text { inside, } \\
\mathrm{Na}_{2} \mathrm{SO}_{4} \mathrm{I} \text { outside }\end{array}$ & 6 & $\begin{array}{c}\mu a / 7 \mathrm{~cm}^{2} \\
244.9 \\
( \pm 82.1)\end{array}$ & $\begin{array}{c}\mu a / 7 \mathrm{~cm}^{2} \\
40.7 \\
( \pm 27.9)\end{array}$ & $\begin{array}{c}\mu a / 7 \mathrm{~cm}^{2} \\
204.2 \\
( \pm 76.1)\end{array}$ & $\begin{array}{c}\mu a / 7 \mathrm{~cm}^{2} \\
220.2 \\
( \pm 82.5)\end{array}$ & $\begin{array}{c}\% \\
93.9 \dagger \\
( \pm 7.09)\end{array}$ \\
\hline $\begin{array}{l}\mathrm{K}_{2} \mathrm{SO}_{4} \mathrm{II} \text { inside, } \\
\mathrm{Na}_{2} \mathrm{SO}_{4} \text { II outside }\end{array}$ & 10 & $\begin{array}{l}187.9 \\
( \pm 86.3)\end{array}$ & $\begin{array}{c}33.6 \\
( \pm 19.5)\end{array}$ & $\begin{array}{c}154.3 \\
( \pm 87.5)\end{array}$ & $\begin{array}{c}167.1 \\
( \pm 89.3)\end{array}$ & $\begin{array}{r}91.6 \dagger \\
( \pm 12.5)\end{array}$ \\
\hline
\end{tabular}

* Potassium flux values were based upon the rate of accumulation of $\mathrm{K}^{+}$(measured with the flame photometer) in the external $\mathrm{Na}_{2} \mathrm{SO}_{4}$ Ringer's solution.

$\dagger$ Mean calculated from the mean value of each individual experiment. Neither of the two values for Na-K flux/ $\mathrm{SCC}$ differs significantly from $100 \%$ ( $\mathrm{p}>0.05$ for both).

sulfate Ringer's solutions II, influx exceeded the current by $17.1 \%$. The differences between the flux values and the currents with the sulfate Ringer's solutions are statistically significant $(\mathrm{p}<$ 0.01 ).

The values for $\mathrm{Na}^{22}$ efflux (from internal to external solutions) are compared with the shortcircuit current in Table III. In the control periods, efflux rates averaged $18.2 \%$ of the current. With both types of sulfate Ringer's solutions, however, efflux values were extremely small, averaging less than $1 \%$ of the current. Because of these negligible rates of efflux, values for sodium influx closely reflect net sodium flux (i.e., influx minus efflux). Hence, the data recorded in Table II suggest that net sodium transport exceeds the short-circuit current with high potassium concentrations in contact with the internal surface of the skins. Accordingly, a series of experiments was performed to determine what other ions were contributing to the electrical events.

Because there is a steep downhill chemical concentration gradient for potassium ions from internal to external solutions, net transcellular movement of this cation might be expected to occur in a direction opposite to that of sodium. In Table

TABLE $V$

Influx and effux values for $\mathrm{S}^{35} \mathrm{O}_{4}$ and $\mathrm{P}^{32} \mathrm{O}_{4}$

\begin{tabular}{lcccc}
\hline \hline & $\begin{array}{c}\text { No. of } \\
\text { experi- } \\
\text { ments }\end{array}$ & $\begin{array}{c}\text { Flux } \\
\text { values }\end{array}$ & SCC & SCC \\
\cline { 5 - 6 } \cline { 4 - 5 } & & $\mu a / 7 \mathrm{~cm}^{2}$ & $\mu a / 7 \mathrm{~cm}^{2}$ & $\%$ \\
$\mathrm{~S}^{35} \mathrm{O}_{4}$ influx & 3 & 3.4 & 144 & 2.4 \\
$\mathrm{~S}^{35} \mathrm{O}_{4}$ efflux & 3 & 3.9 & 157.1 & 2.5 \\
$\mathrm{P}^{22} \mathrm{O}_{4}$ influx & 4 & 0.12 & 175.3 & 0.07 \\
$\mathrm{P}^{32} \mathrm{O}_{4}$ efflux & 3 & 0.11 & 133.6 & 0.03 \\
\hline
\end{tabular}

IV, the rates of accumulation of potassium ions in the external $\mathrm{Na}_{2} \mathrm{SO}_{4}$ Ringer's solution, measured chemically, are expressed as flux values and compared with the concomitant $\mathrm{Na}^{22}$ influx values. With both types of sulfate Ringer's solutions, the mean values for transcellular sodium influx minus potassium flux into the external solution were approximately $7 \%$ less than the short-circuit current. These differences were not statistically significant.

The possible contribution of net transcellular anionic movements to the short-circuit current is considered in Table V. The influx and efflux rates of $\mathrm{S}^{35} \mathrm{O}_{4}$ were closely comparable in magni-

TABLE VI

Relationship of Na influx to short-circuit current at $p H 7.0$ and 8.4 with sulfate Ringer's solutions II

\begin{tabular}{cccc}
\hline $\begin{array}{c}\text { Experi- } \\
\text { ment }\end{array}$ & $\mathrm{SCC}$ & $\mathrm{Na}^{22}$ influx & $\mathrm{Na} / \mathrm{SCC}$ \\
\hline & $\mu a / 7 \mathrm{~cm}^{2}$ & $\mu a / 7 \mathrm{~cm}^{2}$ & $\%$ \\
1 & \multicolumn{3}{c}{$\mathrm{pH} 7.0$} \\
2 & 119.7 & 160.4 & 134 \\
3 & 159.4 & 145.7 & 91.4 \\
4 & 163.2 & 158.2 & 96.9 \\
5 & 90.1 & 105.3 & 116.9 \\
Mean & 103.5 & 149.4 & 144.3 \\
$(\mathrm{SD})$ & 127.2 & 143.8 & 116.7 \\
& $( \pm 29.4)$ & $( \pm 20.0)$ & $( \pm 20.5)$ \\
1 & & $\mathrm{pH} 8.4$ & \\
2 & 152.3 & 173.2 & 113.7 \\
3 & 187.3 & 187.0 & 99.8 \\
4 & 157.5 & 188.6 & 119.7 \\
5 & 171.6 & 187.7 & 109.4 \\
6 & 113.9 & 136.8 & 120.1 \\
7 & 130.9 & 159.6 & 121.9 \\
8 & 226 & 263 & 116.4 \\
Mean & 265.7 & 308.3 & 116 \\
$(\mathrm{SD})$ & 175.7 & 200.5 & 114.6 \\
& $( \pm 46.8)$ & $( \pm 53.0)$ & $( \pm 6.72)$ \\
\hline & & &
\end{tabular}


tude, each averaging less than $3 \%$ of the shortcircuit current. Values for influx and efflux of $\mathrm{P}^{32} \mathrm{O}_{4}$ also were extremely small under conditions of short-circuiting, and although isotopic equilibrium may not have occurred during the 2- to 4hour periods of study (due to the large intracellular pool of phosphate), there is no suggestion of net movement of this anionic species either.

In Table VI, sodium influx is compared with short-circuit current using sulfate Ringer's solutions II with $\mathrm{pH}$ values of 7.0 and 8.4, respectively. Despite this range of hydrogen ion concentrations of the bathing media, the relationships between sodium ${ }^{22}$ influx and short-circuit current were the same as those recorded in Table II.
In view of the existence of a steep downhill electrochemical gradient for sodium ions from external to internal surfaces of the frog skin (i.e., in the direction of net movement), it is necessary to establish that active sodium transport was not abolished by the altered environmental conditions. The results of bidirectional sodium flux measurements are shown in Table VII. The ratios of sodium influx to sodium efflux are compared with the ratios of the chemical concentrations of sodium in the external versus the internal sulfate Ringer's solutions. According to the UssingZerahn equation (3), the flux ratios should equal the concentration ratios during short-circuiting if sodium transport is passive. During the control

TABLE VII

Bidirectional $\mathrm{Na}$ flux measurements during exposure of the internal surface of the frog skin to $K_{2} S_{4} \mathrm{Ringer}^{\prime}$ solutions and the effects of $1.4 \times 10^{-5}$ strophanthin on these ratios

\begin{tabular}{|c|c|c|c|c|c|}
\hline $\begin{array}{c}\text { Experi- } \\
\text { ment }\end{array}$ & Conditions & $\frac{\mathrm{Na}^{22} \text { influx }}{\mathrm{Na}^{21} \text { efflux }}$ & $\frac{\mathrm{Na} \text { conc.* outside }}{\mathrm{Na} \text { conc. inside }}$ & $\frac{\text { Flux ratio }}{\text { Conc. ratio }}$ & $\begin{array}{c}\text { Passive } \\
\text { transport }\end{array}$ \\
\hline \multirow{4}{*}{1} & & umoles $/ \mathrm{hr} / \mathrm{cm}^{2}$ & & & $\%$ of net \\
\hline & Control & $\frac{1.74}{0.108}=16.1$ & $\frac{115}{115}=1.0$ & 16.1 & 6.2 \\
\hline & $\mathrm{SO}_{4}$ Ringer's II & $\frac{1.12}{0.0038}=294.7$ & $\frac{160}{5}=32.0$ & 9.2 & 10.9 \\
\hline & Strophanthin & $\frac{0.71}{0.0197}=36.0$ & $\frac{160}{5.5}=29.1$ & 1.2 & 80.7 \\
\hline \multirow[t]{3}{*}{2} & Control & $\frac{1.59}{0.295}=5.4$ & $\frac{115}{115}=1.0$ & 5.4 & 18.6 \\
\hline & $\mathrm{SO}_{4}$ Ringer's II & $\frac{1.69}{0.016}=105.6$ & $\frac{160}{5.2}=30.8$ & 3.4 & 29.2 \\
\hline & Strophanthin & $\frac{0.79}{0.025}=31.6$ & $\frac{160}{5.7}=28.1$ & 1.1 & 88.9 \\
\hline \multirow[t]{3}{*}{3} & Control & $=6.7$ & $\frac{115}{115}=1.0$ & 6.7 & 14.9 \\
\hline & $\mathrm{SO}_{4}$ Ringer's II & $\frac{0.86}{0.0080}=107.5$ & $\frac{160}{6.1}=26.2$ & 4.1 & 24.4 \\
\hline & Strophanthin & $\frac{0.56}{0.0133}=42.1$ & $\frac{160}{6.2}=25.8$ & 1.6 & 61.3 \\
\hline \multirow[t]{4}{*}{4} & Control & $\frac{2.01}{0.3246}=6.2$ & $\frac{115}{115}=1.0$ & 6.2 & 16.1 \\
\hline & $\mathrm{SO}_{4}$ Ringer's I & $\frac{1.52}{0.0117}=129.9$ & $\frac{122.5}{5.2}=23.6$ & 5.5 & 18.2 \\
\hline & Strophanthin & $\frac{0.35}{0.0187}=18.7$ & $\frac{122.5}{5.6}=21.7$ & 0.9 & 115.9 \\
\hline & Mean values & $\begin{array}{l}\text { Control } \\
\text { SO }_{4} \text { Ringer's } \\
\text { Strophanthin }\end{array}$ & & $\begin{array}{l}8.6 \\
5.6 \\
1.2\end{array}$ & $\begin{array}{l}14.0 \\
20.7 \\
86.7\end{array}$ \\
\hline
\end{tabular}

* Conc. $=$ concentration. 


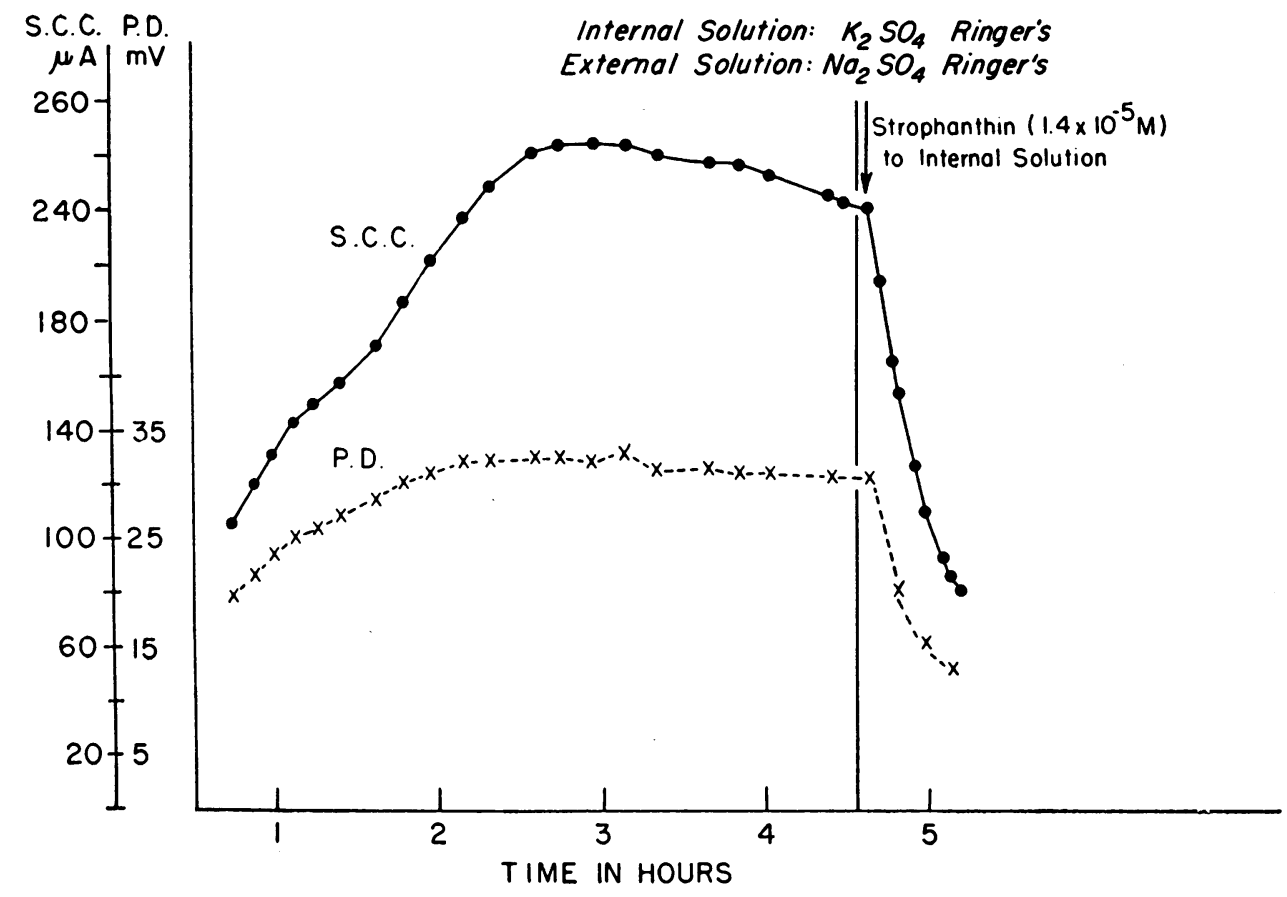

Fig. 3. Effects of Strophanthin in $\mathrm{K}_{2} \mathrm{SO}_{4}$ Ringer's Solution on SCC and PD. See Figure 1 for abbreviations.

periods, with frog Ringer's solutions bathing both borders of the skins, flux ratios exceeded concentration ratios by an average of 8.6. With the sulfate Ringer's system, flux ratios again exceeded concentration ratios by from 3.4 to 9.2 (average, 5.6). The latter observations support the role of active transport in the transcellular movements of sodium. Moreover, the calculated rates of passive sodium influx [ (external sodium concentration/internal sodium concentration) times $\mathrm{Na}^{24}$ efflux values] suggest that passive transfer accounted for only 10.9 to $29.2 \%$ (average, $20.7 \%$ ) of net movement.

Further support for the role of active transport is provided by the effects of strophanthin on the flux ratios. After the addition of this cardiac glycoside to the $\mathrm{K}_{2} \mathrm{SO}_{4}$ Ringer's solution in a $1.4 \times 10^{-5} \mathrm{M}$ final concentration, the shortcircuit current and potential differences fell precipitously (Figure 3 ). In unidirectional flux studies, these bioelectric changes were associated with a marked fall in sodium influx and a slight increase in sodium efflux rates. The simultaneous effects of strophanthin on influx and efflux are shown in Table VII. After addition of strophan- thin, the flux ratios approached the concentration ratios in each experiment, and the average value for the flux ratio/concentration ratio for the four studies was 1.2.

\section{Discussion}

The intracellular potassium activity of the epithelia of the frog skin bathed in anuran Ringer's solutions probably does not exceed $110 \mathrm{mEq}$ per L. Hence the usual chemical concentration gradient favoring potassium diffusion from cell water to internal bathing medium was abolished in our experiments. Furthermore, the skins were maintained in a short-circuited state, and Frazier and Leaf (4) have recently shown that in the toad bladder, under conditions similar to the present ones, there is only a small potential jump across the internal (i.e., serosal) border of the epithelia during short-circuiting. The probability seems high indeed, therefore, that the combined electrochemical gradient for potassium across the internal plasma membrane was reversed. Consequently, a potassium diffusion current generated by an electrochemical gradient of potassium oriented from cell water to internal medium could 
Epithelial Cell

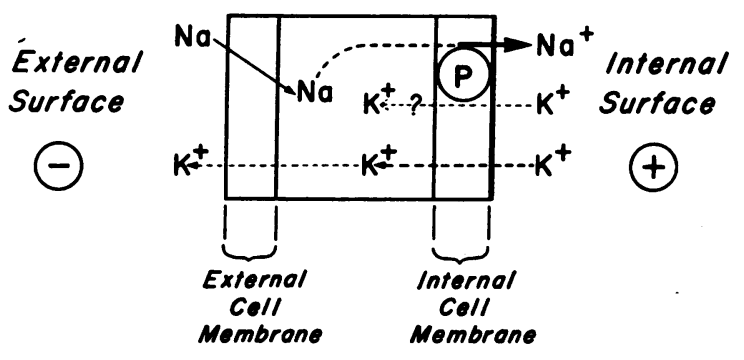

Fig. 4. A MODification OF THE KOEFOEd-JohnSEN MODEL OF SODIUM TRANSPORT BY THE EPITHELIAL CELLS OF THE FROG SKIN. This figure is intended to describe the patterns observed under the specific conditions of these studies. The sodium pump accounts for the net transfer of positive charge across the internal border; hence, any linkage between sodium and potassium active transport cannot be in a $1: 1$ ratio. The net movement of potassium is from internal to external solutions.

not have contributed appreciably in a positive direction to the observed short-circuit current, ${ }^{1}$ nor does this current appear to be explicable on the basis of net anionic transport. Finally, the same relationships between $\mathrm{Na}$ transport and the short-circuit current were observed when the $\mathrm{pH}$ of the bathing media was 7.0, 7.4, and 8.4, and no evidence emerges from these studies that diffusion of hydrogen ions into the internal bathing solutions made a major contribution to the electrical events. By exclusion sodium ions may be implicated in the genesis of the short-circuit current, and the experimental observations are in accord with the view that, under steady-state conditions, active sodium transport accounts for the great majority of the charge transfer across the internal border of the epithelia. As yet, no explanation may be offered for the large transients in short-circuit current and potential difference that occurred immediately after switching from the low potassium to the high potassium internal solutions.

In Figure 4, a modification of the KoefoedJohnsen and Ussing model for the frog skin is proposed in explanation of the present data. The

1 If the short-circuit current, which measures transcellular movement of electric charge, were dependent upon $\mathrm{Na}^{+}$diffusion into the cells and $\mathrm{K}^{+}$diffusion out of the cells (across the external and internal plasma membranes, respectively), the absence of $\mathrm{K}^{+}$diffusion should have eliminated the current. sodium pump is shown to operate electrogenically, accounting for the transfer of positive charge across the internal border of the epithelial cells. An essential corollary of an electrogenic sodium pump is that any coupling between active $\mathrm{Na}$ and active $K$ transport could not have occurred in a $1: 1$ ratio, although some form of dependence between sodium extrusion and potassium accumulation intracellularly may well exist.

The evidence presented in this and the preceding paper (2) in favor of electrogenic sodium transport and against a tightly coupled $1: 1 \mathrm{Na}: \mathrm{K}$ pump is concerned only with the isolated frog skin exposed to unusual environmental conditions. However, Frazier and Leaf (4) and Essig and Leaf (5) have obtained evidence that favors electrogenic sodium transport in the isolated toad bladder; Burg, Grollman, and Orloff (6) have presented preliminary observations suggesting that sodium and potassium transport in vitro by mammalian renal tubules is not coupled in a $1: 1$ ratio; and Mullins and Frumento ( 7 ) have adduced evidence consistent with electrogenic $\mathrm{Na}^{+}$ transport in the sartorius muscle of the frog. It would seem important, therefore, to re-evaluate systematically the evidence for a $1: 1$ coupled $\mathrm{Na}: \mathrm{K}$ pump in a variety of other polar and nonpolar sodium transporting cell types.

\section{Summary}

Studies were performed on short-circuited isolated frog skins exposed at their internal surfaces to potassium concentrations that exceeded estimated intracellular values. Sodium was substituted for potassium in equimolar concentrations in the external bathing media. The Ringer's solutions in contact with both surfaces of the skins were chloride-free, and the anions were comprised of sulfate and phosphate.

The data demonstrate the persistence of the short-circuit current under these environmental conditions; hence, net transfer of electric charge occurred across the internal, as well as the external, border of the epithelia, despite the fact that the electrochemical gradient for potassium no longer favored net movement of this cation from cell water to internal bathing medium. Indeed, net transcellular movement of potassium took place from internal to external solutions. No net 
movements of either phosphate or sulfate were evident in the short-circuited preparations, and thus anions could not be implicated in the genesis of the electrical events. Finally, no evidence emerged that hydrogen ion movements contribute appreciably to the short-circuit current.

The measurements of sodium fluxes support the view that net transcellular sodium movements from external to internal solutions largely if not completely account for the observed short-circuit currents. Furthermore, approximately $80 \%$ of the net sodium flux was due to active transport, and the passive movements of sodium were largely counterbalanced by the passive movements of potassium in the opposite direction.

These observations are consistent with the view that the sodium pump operated electrogenically. This in turn would indicate that any coupling between active sodium extrusion from the cells and active potassium entry into the cells across the internal border of the epithelia did not occur in a $1: 1$ ratio.

\section{References}

1. Koefoed-Johnson, V., and H. H. Ussing. The nature of the frog skin potential. Acta physiol. scand. 1958, 42, 298.

2. Bricker, N. S., T. Biber, and H. H. Ussing. Exposure of the isolated frog skin to high potassium concentrations at the internal surface. I. Bioelectric phenomena and sodium transport. J. clin. Invest. 1963, 42, 88.

3. Ussing, H. H., and K. Zerahn. Active transport of sodium as the source of electric current in the short-circuited isolated frog skin. Acta physiol. scand. 1951, 23, 110.

4. Frazier, H. W., and A. Leaf. The electrical characteristics of active sodium transport in the toad bladder. J. gen. Physiol. 1963, 46, 491.

5. Essig, A., and A. Leaf. The role of potassium in active transport of sodium by the toad bladder. J. gen. Physiol. 1963, 46, 505.

6. Burg, M. B., E. F. Grollman, and J. Orloff. Lack of coupling between the active efflux of sodium and the influx of potassium in rabbit renal tubules (abstract). J. clin. Invest. 1963, 42, 921.

7. Mullins, L. J., and A. S. Frumento. The concentration dependence of sodium efflux from muscle. J. gen. Physiol. 1963, 46, 629. 